\title{
PENGOLAHAN MINYAK JARAK PAGAR MENJADI EPOKSI SEBAGAI BAHAN BAKU MINYAK PELUMAS
}

\author{
(Processing of Jatropha curcas L. Oil for Epoxy \\ as Raw Material of Lubricant Base Oil)
}

Oleh/By :

R. Sudradjat, R. Ariatmi \& D. Setiawan

\begin{abstract}
Oil content of Jatropha curcas is considerably high, but it also contains toxin that makes unsuitable for edible oil. Jatropha oil is composed by unsaturated fatty acid that make this oil easily become rancid or unsuitable as raw material for biodiesel. Hence, it is necessary to find more appropriate uses of the oil with such characteristics. One of these alternatives is the utilization of jatropha oil for making automotive lubricant base oil. So far lubricant base oil was mostly made from fossil oil.

The aim of this research is to examine characteristics of jatropha oil in relevance with lubricant base oil properties, and to determine optimum condition in making epoxy as an intermediate product.

Methodology used are as follows: 1). Oil extraction for determining the yield of jatropha oil originated from Kebumen, NTB, and Lampung; 2). Characteristics of jatropha oil comprises of : viscosity index, flash point, pourpoint, acid number, saponoification number and iod number; 3). Epoxydation reaction using variable: a). Temperature $70^{\circ} \mathrm{C}$; b). Time: $0 ; 0.5 ; 1.0 ; 1.5 ; 2.0 ; 2.5 ; 3.0 ; 3.5 ; 4.0 ; 4.5 ; 5.0$ and 5.5 bours; $c$. $\mathrm{H}_{2} \mathrm{SO}_{4}$ catalyst concentration of $1 \%$ $(v / v)$. Ratio of bydrogen peroxyde vs acetic acid are $1: 0.07 ; 1: 0.15 ; 1: 0.22$ and $1: 0.30$. Parameters to be observed is the oxyrane number.

The results are as follow:

1. Physical and chemical properties of jatropha oil could met with the required properties for lubricant base oil except saponification number and pourpoint.

2. FTIR and GC analyses showed that jatropha oil needs improvement in some physical and chemical properties such as interesterification with other good bio-oil, blending with other sinthetic ester, decreasing of unsaturated fatty acid.

3. Variation of bydrogen peroxide and acetic acid ratios significantly influenced the oxyrane number of the produced epoxy.

4. The bestprocess condition achieved at 3 hours reaction time, $60^{\circ} \mathrm{C}$ and ratio bydrogen to acetic acid concentration of 1 : 0.07 mol which giving 4.26 oxyrane number.

5. Completion of this research is necessary in convertion of epoxy from jatropha oil into lubricant base oil (polyol).
\end{abstract}

Keywords: Lubricant base oil, jatropha oil, oleo-chemicals, oxyrane number

\begin{abstract}
ABSTRAK
Kandungan minyak dalam jarak pagar (Jatropha curcas L.) cukup tinggi, tetapi di dalamnya terkandung racun, sehingga tidak dapat digunakan sebagai minyak makan. Di dalam minyak jarak pagar terkandung ikatan rangkap yang mengakibatkan minyak menjadi tidak stabil sehingga kurang sesuai untuk dibuat biodiesel. Oleh karena itu, perlu dilakukan penelitian untuk mencari alternatif penggunaan lain dari minyak tersebut yang lebih sesuai dengan karakteristik sifatnya. Salah satu
\end{abstract}


alternatif produk yang akan diteliti adalah untuk pembuatan epoksi yaitu bahan baku untuk pembuatan pelumas dasar (pelumas mesin otomotif). Selama ini minyak pelumas dasar banyak dibuat menggunakan minyak bumi.

Penelitian ini bertujuan untuk mengetahui karakteristik minyak jarak pagar dihubungkan dengan penggunaannya sebagai minyak pelumas serta untuk mendapatkan kondisi optimum pada proses pembuatan minyak epoksi sebagai produk antara pada pembuatan minyak pelumas dari minyak jarak pagar.

Metode penelitian yang dilakukan adalah: 1). Ekstraksi minyak jarak pagar untuk mengetahui rendemen minyak jarak pagar asal Kebumen, NTB dan Lampung; 2). Penelitian karakteristik minyak jarak pagar. Penelitian ini meliputi sifat fisika dan kimia yaitu: indeks viskositas, flash point, pour point, bilangan asam, bilangan penyabunan dan bilangan iod; 3). Reaksi epoksidasi minyak jarak yaitu dengan variabel kondisi proses: a). Suhu: $70^{\circ} \mathrm{C}$ dan b). Waktu : $0 ; 0,5 ; 1,0 ; 1,5 ; 2,0 ; 2,5 ; 3,0 ; 3,5 ; 4,0 ; 4,5 ; 5,0$ dan $5,5 \mathrm{jam}$, Konsentrasi katalis H2SO4 1\% (v/v), Perbandingan konsentrasi hidrogen peroksida dengan asam asetat adalah $1: 0,07 ; 1: 0,15 ; 1: 0,22$ dan $1: 0,30$. Parameter yang diteliti yaitu bilangan oksiran.

Hasil penelitian menunjukkan:

1. Sifat fisik dan kimia minyak jarak pagar, memenuhi persyaratan sebagai pelumas dasar kecuali pada persyaratan bilangan penyabunan dan pourpoint.

2. Hasil analisa pengujian FTIR dan GC menunjukkan perbaikan sifat fisik dan kimia minyak jarak pagar. Beberapa contoh modifikasi yang dapat dilakukan adalah interesterifikasi dengan minyak nabati lain, blending dengan ester sintestis lain, mengurangi ketidakjenuhan sehingga minyak menjadi lebih stabil.

3. Perbedaan penambahan konsentrasi asam asetat dengan hidrogen peroksida berpengaruh terhadap bilangan oksiran pada senyawa epoksi yang dihasilkan.

4. Kondisi terbaik dicapai pada 3 jam operasi dengan suhu $60^{\circ} \mathrm{C}$ dan perbandingan konsen-trasi hidrogen peroksida dengan asam asetat 1:0,07 mol dengan besarnya bilangan oksiran 4,26.

5. Masih diperlukan penelitian lanjutan khususnya mengenai teknologi pengolahan epoksi menjadi minyak pelumas (poliol).

Kata kunci: Minyak pelumas dasar, minyak jarak pagar, oleo-kimia, bilangan oksiran

\section{PENDAHULUAN}

Fungsi utama dari minyak pelumas otomotif (oli) adalah mengurangi gesekan dan keausan antara dua bidang atau permukaan yang bersinggungan, memperpanjang usia pakai serta fungsi lainnya, membantu transfer panas dan mencegah korosi. Formulasi pelumas yang banyak digunakan adalah terdiri dari 70 - 90\% minyak pelumas dasar yang dicampur dengan bahan aditif untuk memodifikasi sifat-sifat alamiahnya (yaitu stabilitas untuk oksidasi, hidrolisis, suhu, viskositas dan indeks viskositas dan korosi). Minyak pelumas dasar yang paling banyak digunakan adalah minyak mineral yaitu campuran dari beberapa minyak bumi, selain itu dapat digunakan juga minyak pelumas dasar jenis minyak nabati, atau minyak sintetis yang berasal dari minyak bumi atau minyak nabati (Askew, 2004).

Saat ini kebutuhan akan minyak bumi meningkat, sedangkan persediaannya menipis. Keadaan ini memacu penggunaan minyak pelumas nabati sebagai bahan dasar. Keunggulan minyak pelumas nabati dari minyak mineral adalah stabilitas termal, sifat alir, indeks viskositas dan stabilitas penguapan. Oleh karena itu, minyak nabati memberikan kinerja yang lebih baik selain juga bahan bakunya terbarukan. 
Pada penelitian ini dilakukan pembuatan minyak pelumas dasar dari bahan nabati yaitu minyak jarak pagar (Jatropha curcas L.). Tujuan dari penelitian ini adalah untuk mengetahui karakteristik minyak jarak pagar sebagai bahan pelumas, serta mendapatkan kondisi optimum pada proses pembuatan epoksi dari minyak jarak pagar. Sebelum dibuat minyak pelumas nabati, minyak jarak pagar terlebih dahulu diubah menjadi epoksi. Alasan pemilihan minyak jarak pagar adalah karena dapat tumbuh dengan cepat, serta tahan terhadap musim panas (Guibitz et al., 1999). Selain itu, karena tingginya kandungan minyak dan adanya ikatan rantai karbon rangkap yang diperlukan pada proses epoksidasi untuk menghasilkan epoksi minyak jarak pagar yang bersifat reaktif sebagai bahan baku untuk pembuatan minyak pelumas (poliolester). Pembuatan minyak jarak untuk minyak pelumas memberikan nilai tambah yang lebih tinggi daripada pembuatan untuk biodisel. Harga biodisel di pasar sekitar Rp 4.000/liter, sedangkan minyak pelumas berkisar antara Rp 15.000 - 35.000/liter. Pelumas dalam pemakaiannya lebih butuh perhatian, yaitu harus diganti secara berkala. Setiap mesin atau bagian kendaran memerlukan pelumas dengan spesifikasi tertentu, disamping itu pelumas juga harus mengandung bahan-bahan tertentu yang dapat mendukung tugasnya (Nugroho, 2005).

\section{BAHAN DAN METODE}

\section{A. Lokasi}

Penelitian dilaksanakan di Laboratorium Kimia dan Energi, Pusat Litbang Hasil Hutan, Bogor dan Laboratorium Teknologi Industri, Universitas Jayabaya, Jakarta yang meliputi persiapan bahan baku dan pengujian/analisis komponen kimia fisik minyak dan pelumas dasar dari jarak pagar.

\section{B. Bahan dan Alat}

Bahan baku yang digunakan dalam penelitian ini adalah biji jarak pagar (Jatropha curcas L.), sedangkan bahan kimia yang digunakan adalah asam asetat, hidrogen peroksida, natrium hidrogen karbonat, asam sulfat, etanol, larutan hidrogen bromida, flourboric acid (HBF), etilen glikol, metanol, air suling dan lain-lain.

Alat-alat yang digunakan untuk memperoleh minyak jarak terdiri dari oven dan kempa hidrolik, sedangkan untuk proses epoksidasi dan pembentukan poliol sampai dengan pembentukan poliolester terdiri dari labu leher tiga yang dilengkapi dengan pengaduk, termometer, pengambil cuplikan dan pemanas (hot plate stirrer), gelas ukur, pipet, alat titrasi, labu ukur, gelas piala, erlenmeyer, alat distilasi vakum dan lain-lain.

\section{Prosedur Kerja}

Metode penelitian meliputi beberapa tahapan kegiatan yaitu perlakuan biji jarak, proses pengambilan minyak jarak pagar, karakterisisasi minyak jarak pagar, proses reaksi epoksidasi minyak jarak, uji epoksi, proses reaksi pembentukan poliol, uji poliol, proses pembentukan poliolester, uji poliolester dan perhitungan kelayakan pada proses produksi poliolester minyak jarak pagar. Diagram alir penelitian dapat dilihat pada Gambar 1. 


\section{Ekstraksi minyakjarak pagar}

Minyak jarak diekstrak dari bijinya dengan cara terbaik yaitu untuk memperoleh kualitas minyak jarak yang jernih, kadar kotoran yang rendah, bilangan asam yang rendah dan kadar air yang rendah. Untuk itu biji jarak yang masih ada tempurungnya terlebih dahulu dikukus selama 2 jam, kemudian dikeringkan dalam oven selama 2 jam, dikupas, daging bijinya digiling sampai halus dan secepatnya dipres menggunakan alat pres hidrolik manual. Dilakukan analisis terhadap minyak jarak pagar yaitu bilangan iod, bilangan asam, kadar air dan rendemen. Dalam penelitian ini diperiksa rendemen minyak dari biji jarak pagar asal Kebumen, Nusa Tenggara Barat dan Lampung.

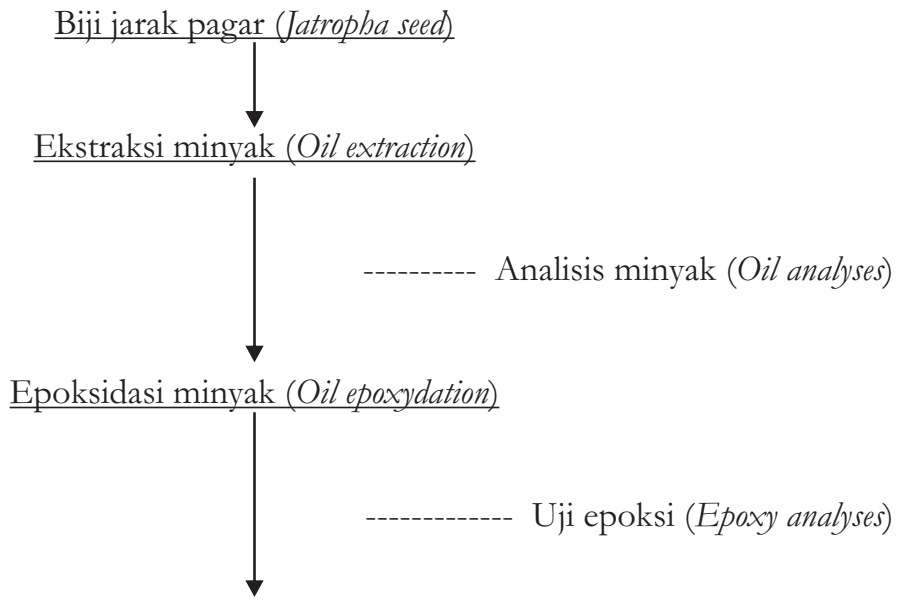

Pembuatan poliol (Polyol making)

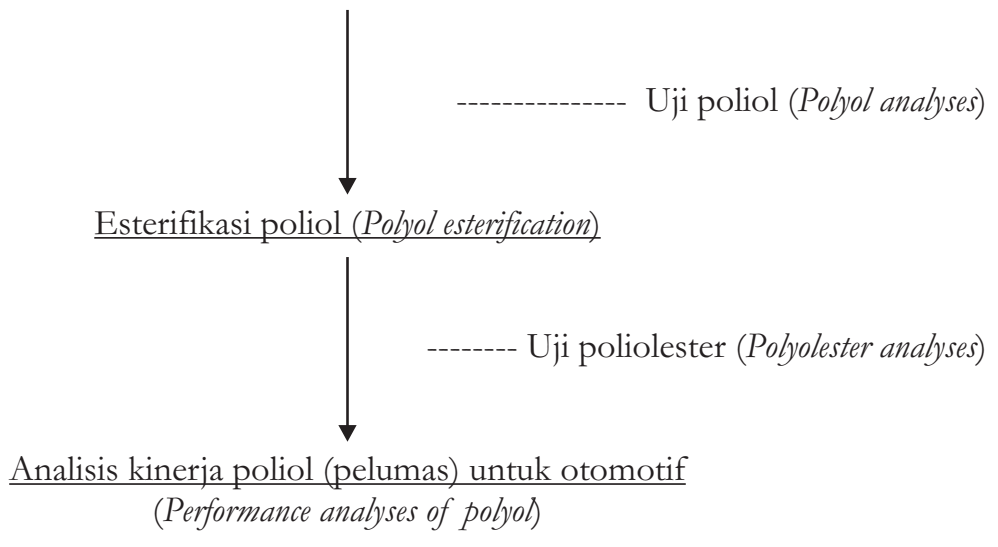

Gambar1. Diagram alir pengolahan minyak jarak pagar menjadi minyak pelumas (Dalam penelitian ini dibatasi sampai tahap pembuatan epoksi)

Figure 1. Flow diagram of jatropha oil processing to lubricant oil (This experiment is limitted to epoxy production) 


\section{Penelitian karakteristik minyak jarak pagar}

Penelitian karakteristik minyak jarak pagar dilakukan terhadap sifat fisika dan kimia. Penelitian sifat fisika meliputi: indeks viskositas, flash point (titik nyala), pour point (titik tuang) dan densitas. Penelitian sifat kimia meliputi bilangan asam, bilangan penyabunan, bilangan iod.

\section{Reaksi epoksidasi minyak jarak pagar}

Mula-mula minyak jarak pagar sebanyak $100 \mathrm{ml}$, asam asetat $99 \%$ dan katalis asam sulfat dimasukkan dalam labu leher tiga, serta hidrogen peroksida $\left(\mathrm{H}_{2} \mathrm{O}_{2}\right) 50 \%$ dimasukkan beberapa tetes. Larutan dipanaskan selama 2 jam sambil diaduk dengan pengaduk magnet, sedangkan pertambahan katalis divariasikan sesuai metoda penelitian. Pengadukan dilakukan agar minyak terdispersi. Produk berupa minyak jarak terepoksidasi sebanyak $15 \mathrm{ml}$ diambil pada selang waktu 30 menit untuk dianalisa bilangan oksirannya dan dinetralisasi untuk menghilangkan sisa asam serta mendinginkannya dengan menggunakan 7,2 ml larutan jenuh natrium hidrogen karbonat $\left(\mathrm{NaHCO}_{3}\right)$, kemudian ditambahkan beberapa ml air suling sampai bebas dari asam. Untuk mengeluarkan sisa asam, campuran tersebut dimasukkan ke dalam labu pemisah dan dikocok. Lapisan air pada bagian bawah yang terbentuk kemudian dikeluarkan. Epoksi minyak yang dihasilkan dianalisa bilangan oksiran, bilangan asam dan bilangan iod.

Kondisi proses epoksidasi adalah sebagai berikut:

$\&$ Suhu : $70^{\circ} \mathrm{C}$

Waktu : $0 ; 0,5 ; 1,0 ; 1,5 ; 2,0 ; 2,5 ; 3,0 ; 3,5 ; 4,0 ; 4,5 ; 5,0$ dan 5,5 jam.

Konsentrasi katalis $\mathrm{H}_{2} \mathrm{SO}_{4} 1 \%(\mathrm{v} / \mathrm{v})$.

Perbandingan konsentrasi hidrogen peroksida $\left(\mathrm{H}_{2} \mathrm{O}_{2}\right)$ dengan asam asetat. $\left(\mathrm{CH}_{3} \mathrm{COOH}\right)$ sebagai berikut: $1: 0,07 ; 1: 0,15 ; 1: 0,22$ dan $1: 0,30$.

Parameter yang diteliti adalah bilangan oksiran.

\section{HASIL DAN PEMBAHASAN}

\section{A. Rendemen Minyak Jarak Pagar}

Data rendemen masing-masing minyak dari tiga daerah tersebut di atas dapat dilihat pada Tabel 1. Rendemen minyak dari tiap daerah (Tabel 1) menunjukkan hasil yang berbeda, meskipun diketahui bahwa kandungan minyak dalam biji jarak adalah sekitar 40 - 45\% (Sudradjat, 2006). Hal yang menyebabkan adanya perbedaan nilai rendemen adalah tempat tumbuh, iklim, waktu panen, musim, faktor genetik, cara ekstraksi minyak. Beberapa perlakuan dan kondisi biji sebelum dipres mempengaruhi rendemen dan kualitas minyak, Pengepresan dengan pemanasan akan menghasilkan rendemen minyak tinggi, tetapi bilangan asam tinggi. Demikian pula kandungan air yang tinggi dari biji akan mengakibatkan tingginya bilangan asam karena memperbesar kemungkinan terjadinya proses hidrolisis minyak. Hidrolisis minyak akan membentuk asam lemak bebas sehingga bilangan asam menjadi tinggi. Perlakuan awal terhadap biji sebelum dipres juga akan mempengaruhi kandungan air dalam bahan. Perlakuan terhadap biji dengan dikukus dan dioven sebelum dipres, memberikan hasil bilangan asam yang berbeda. 
Tabel1. Rendemen dan bilangan asam minyak jarak pagar dari biji asal Kebumen, NTB dan Lampung

Table 1. Yield and acid number of jatropha oil from seed originated from Kebumen, NTB and Lampung

\begin{tabular}{|c|l|c|c|c|c|}
\hline No. & $\begin{array}{c}\text { Asal daerah biji } \\
\text { jarak } \\
\text { (Seed originated) }\end{array}$ & $\begin{array}{c}\text { Rendemen } \\
\text { dengan } \\
\text { tempurung } \\
\text { (Yield with shell), } \\
\%\end{array}$ & $\begin{array}{c}\text { Rendemen } \\
\text { tanpa tem- } \\
\text { purung } \\
\text { (Yield without } \\
\text { shell), \% }\end{array}$ & $\begin{array}{c}\text { Bilangan asam } \\
\text { (Acid number), } \\
\mathrm{mg} \mathrm{KOH/g}\end{array}$ & $\begin{array}{c}\text { Kadar air } \\
\text { (MOisture), } \\
\%\end{array}$ \\
\hline 1. & Kebumen & 16,83 & 42,02 & 5,28 & 0,97 \\
\hline 2. & $\begin{array}{l}\text { Nusa Tenggara } \\
\text { Barat (NTB) }\end{array}$ & 20,30 & 41,66 & $\begin{array}{c}3,97 ; 12,66 \\
\text { dan } 10,0\end{array}$ & 1,20 \\
\hline 3. & Lampung & 18,30 & 28,61 & 16 & 1,03 \\
\hline
\end{tabular}

\section{B. Sifat Fisik Minyak Jarak Pagar}

Pada pengolahan minyak mineral dapat dihasilkan beberapa pelumas dasar dengan tingkat viskositas yang berbeda antara satu dengan lainnya. Pada Tabel 2 terlihat beberapa jenis pelumas dasar baik dari minyak nabati maupun minyak mineral. Dari satu jenis minyak mineral dapat diperoleh beberapa jenis pelumas dasar yang berbeda-beda tingkat viskositasnya. Sifat minyak jarak pagar sebagai pelumas dasar diharapkan sama atau mendekati sifat-sifat dasar minyak mineral.

Tabel 2. Perbandingan sifat fisik pelumas dasar beberapa minyak nabati dan mineral

Table 2. Comparison between the physical properties of lubricant base oil from some bio and mineral oils

\begin{tabular}{|c|c|c|c|c|c|}
\hline $\begin{array}{l}\text { Jenis minyak } \\
\text { (Kind of oils) }\end{array}$ & $\begin{array}{c}\text { Viskositas } \\
\text { (Viscosity) } \\
40^{\circ} \mathrm{C} \mathrm{cSt}\end{array}$ & $\begin{array}{l}\text { Viskositas } \\
\text { (Viscosity) } \\
100^{\circ} \mathrm{C} \mathrm{cSt}\end{array}$ & $\begin{array}{c}\text { Indeks } \\
\text { Viskositas } \\
\text { (Viscosity } \\
\text { index) }\end{array}$ & $\begin{array}{c}\text { Titik } \\
\text { Tuang } \\
\text { (Pour } \\
\text { point), }{ }^{O} \mathrm{C}\end{array}$ & $\begin{array}{c}\text { Titik } \\
\text { nyala } \\
\text { (Flash } \\
\text { point), }{ }^{\circ} \mathrm{C}\end{array}$ \\
\hline \multicolumn{6}{|c|}{ Minyak Nabati (Bio oil) : } \\
\hline $\begin{array}{l}\text { Minyak jarak pagar } \\
\text { (Jatropha curcas oil) }\end{array}$ & 34,17 & 7,95 & 217 & 0 & 270 \\
\hline $\begin{array}{l}\text { Minyak jarak } \\
\text { (Castor oi) }\end{array}$ & 295,4 & 20,34 & 87 & -10 & 307 \\
\hline $\begin{array}{l}\text { Minyak kelapa } \\
\text { (Coco oil) }\end{array}$ & 27,7 & 6,1 & 175 & - & - \\
\hline $\begin{array}{l}\text { Minyak bunga matahari } \\
\text { (Sunflower oil) }\end{array}$ & 39,9 & 8,6 & 206 & -12 & 252 \\
\hline
\end{tabular}


Tabel (Table) 2. Lanjutan (Continued)

\begin{tabular}{|c|c|c|c|c|c|}
\hline $\begin{array}{l}\text { Jenis minyak } \\
\text { (Kind of oils) }\end{array}$ & $\begin{array}{l}\text { Viskositas } \\
\text { (Viscosity) } \\
40^{\circ} \mathrm{C} \mathrm{cSt}\end{array}$ & $\begin{array}{l}\text { Viskositas } \\
\text { (Viscosity) } \\
100^{\circ} \mathrm{C} \mathrm{cSt}\end{array}$ & $\begin{array}{c}\text { Indeks } \\
\text { Viskositas } \\
\text { (Viscosity } \\
\text { index) }\end{array}$ & $\begin{array}{c}\text { Titik } \\
\text { Tuang } \\
\text { (Pour } \\
\text { point), }{ }^{\circ} \mathrm{C}\end{array}$ & $\begin{array}{c}\text { Titik } \\
\text { nyala } \\
\text { (Flash } \\
\text { point), }{ }^{\circ} \mathrm{C} \\
\end{array}$ \\
\hline $\begin{array}{l}\text { Minyak lobak } \\
\text { (Rapeseed oil) }\end{array}$ & 36,2 & 8,2 & 211 & -18 & 346 \\
\hline $\begin{array}{l}\text { Minyak kedelai } \\
\text { (Soybean oil) }\end{array}$ & 28,9 & 7,6 & 246 & -9 & 325 \\
\hline $\begin{array}{l}\text { Minyak kelapa sawit } \\
\text { (Palm oil) }\end{array}$ & 39,7 & 8,2 & 188 & 18 & - \\
\hline \multicolumn{6}{|c|}{ Minyak Mineral (Mineral oil) : } \\
\hline HVI-60 & - & $4,5-5,0$ & 103 & 0 & 204 \\
\hline HVI-95 & - & $6,9-7,6$ & 100 & 15 & 210 \\
\hline HVI-160S & - & $11,1-12,2$ & 100 & 15 & 230 \\
\hline HVI-160B & - & $11,1-12,2$ & 99 & 15 & 230 \\
\hline HVI-650 & - & $31,6-34,7$ & 96 & 15 & 267 \\
\hline HVI-350 & - & $50-54$ & - & 15 & 267 \\
\hline PAO (Polyalphaolefin) & $2-100$ & $2-100$ & $125-140$ & -50 & - \\
\hline POE (Polyolester) & 76,7 & 11,3 & 214 & - & 285 \\
\hline
\end{tabular}

Sumber (Source) : La Puppung (1986)

\section{Indeks viskositas}

Pelumas dasar minyak nabati termasuk minyak jarak pagar yang mempunyai indeks viskositas yang sangat tinggi dibandingkan dengan minyak mineral. Indeks viskositas merupakan pengukuran perubahan viskositas relatif terhadap perubahan temperatur antara suhu $40^{\circ} \mathrm{C}$ dan $100^{\circ} \mathrm{C}$. Nilai indeks viskositas pelumas terbagi menjadi 3 golongan : (1) indeks viskositas rendah atau Low Viscosity Index (LVI) adalah pelumas yang memiliki indeks viskositas lebih rendah dari 40. (2) indeks viskositas sedang atau Medium Viscosity Index (MVI) adalah pelumas yang memiliki indeks viskositas antara 40 sampai dengan 80. (3) indeks viskositas tinggi atau High Viscosty Index (HVI) adalah pelumas yang memiliki indeks viskositas lebih besar daripada 80. Hasil pengujian indeks viskositas minyak jarak pagar sebesar 217, menunjukkan bahwa minyak jarak pagar termasuk minyak yang mempunyai indeks viskositas tinggi (HVI). Jika dibandingkan dengan indeks viskositas minimum beberapa pelumas dengan angka viskositas SAE rangkap seperti yang terdapat pada Tabel 3, maka indeks viskositas minyak jarak pagar lebih tinggi dari pada pelumas dengan SAE 
rangkap tersebut. Zat cair biasanya akan mengalami perubahan viskositas bila terjadi perubahan temperatur, bila temperatur naik viskostas akan turun. Pelumas yang baik adalah pelumas yang memiliki indeks viskositas tinggi, artinya semakin kecil perubahan viskositas karena perubahan temperatur. Jika indeks viskositas minyak jarak pagar dibandingkan dengan minyak nabati lain, maka indeks viskositas minyak jarak pagar setara dengan rapeseed oil dan di bawah minyak kedelai. Apabila indeks viskositas minyak jarak pagar dibandingkan dengan pelumas dasar sintesis, dari Tabel 2 tampak bahwa indeks viskositas minyak jarak pagar lebih tinggi dari PAO dan hampir sama dengan POE.

Tabel3. Indeks viskositas minimum beberapa pelumas dengan angka viskositas SAE

Table 3. Minimum viscosity index of some lubricant oils and its SAE viscosity

\begin{tabular}{|c|c|}
\hline $\begin{array}{c}\text { SAE viskositas rangkap } \\
\text { (Double SAE viscosity) }\end{array}$ & $\begin{array}{c}\text { Indeks viskositas minimum } \\
\text { (Minimum viscosity index) }\end{array}$ \\
\hline $5 \mathrm{~W}-20$ & 127 \\
\hline $5 \mathrm{~W}-30$ & 180 \\
\hline $5 \mathrm{~W}-50$ & 230 \\
\hline $10 \mathrm{~W}-30$ & 145 \\
\hline $10 \mathrm{~W}-40$ & 169 \\
\hline $10 \mathrm{~W}-50$ & 190 \\
\hline $20 \mathrm{~W}-40$ & 113 \\
\hline $20 \mathrm{~W}-50$ & 133 \\
\hline
\end{tabular}

Sumber (Source) : La Puppung (1986)

Jika dibandingkan dengan pelumas dasar ex-Arabian Light Crude, maka berdasarkan Tabel 2, viskositas minyak jarak pagar pada $100^{\circ} \mathrm{C}$ sebesar $7,95 \mathrm{cSt}$ terletak antara HVI-95 dan HVI 160S. Jika dibandingkan dengan tingkat visikositas pelumas motor seperti pada Tabel 4, maka visikositas minyak jarak pagar setingkat SAE 20. Berdasarkan Tabel 5 tentang klasifikasi pelumas industri menurut ISO (ASTM 2422), maka tingkat visikositas minyak jarak pagar setara dengan ISO VG 32. Nilai visikositas minyak jarak pagar ini, termasuk pada spesifikasi viskositas minyak mineral yang saat ini digunakan sebagai formulasi pelumas otomotif maupun industri. Gambar 2 menunjukkan viskositas dan indeks viskositas beberapa jenis pelumas dasar. 
Tabel 4. Tingkat viskositas pelumas motor (SAE J 300, Maret 1982)

Table 4. Viscosity rate of motor lubricant (SAE J 300, March 1982)

\begin{tabular}{|c|c|c|c|c|c|}
\hline \multirow[t]{2}{*}{\begin{tabular}{|c} 
Angka \\
viskositas SAE \\
(SAE viscosity \\
number)
\end{tabular}} & \multicolumn{2}{|c|}{$\begin{array}{c}\text { CCS viskositas } \\
\text { maksimum } \\
\text { (Maximum CCS viscosity) }\end{array}$} & \multirow[t]{2}{*}{$\begin{array}{c}\text { Suhu tekanan } \\
\text { maksimum } \\
\text { (Maximum borderline } \\
\text { pumping temperature) }{ }^{\circ} \mathrm{C}\end{array}$} & \multicolumn{2}{|c|}{$\begin{array}{l}\text { Viskositas pada } 100^{\circ} \mathrm{C} \\
\left.\text { (Viscosity at } 100^{\circ} \mathrm{C}\right) \mathrm{cSt}\end{array}$} \\
\hline & ${ }^{\circ} \mathrm{C}$ & Vd (Poise) & & Minimum & Maksimum \\
\hline $0 \mathrm{~W}$ & -30 & 32,5 & -35 & 3,8 & - \\
\hline $5 \mathrm{~W}$ & -25 & 35 & -30 & 3,8 & - \\
\hline $10 \mathrm{~W}$ & -20 & 35 & -25 & 4,1 & - \\
\hline $15 \mathrm{~W}$ & -15 & 35 & -20 & 5,6 & - \\
\hline $20 \mathrm{~W}$ & -10 & 45 & -15 & 5,6 & - \\
\hline $25 \mathrm{~W}$ & -5 & 60 & -10 & 9,3 & - \\
\hline 20 & - & - & - & 5,6 & $<9,3$ \\
\hline 30 & - & - & - & 9,3 & $<12,5$ \\
\hline 40 & - & - & - & 12,5 & $<16,3$ \\
\hline 50 & - & - & - & 16,3 & $<21,9$ \\
\hline
\end{tabular}

Sumber (Source) : La Puppung (1986)

\section{Flash point}

Flash point atau titik nyala digunakan untuk mengetahui saat awal pelumas akan terbakar atau timbul nyala api saat berada dalam mesin. Pada Tabel 2 menunjukkan bahwa flash point minyak nabati lebih tinggi dibandingkan dengan minyak mineral dan flash point minyak jarak pagar adalah sebesar $270^{\circ} \mathrm{C}$, data ini menunjukkan bahwa flash point minyak jarak pagar lebih besar dibandingkan dengan minyak mineral yang biasanya digunakan untuk formulasi pelumas (minimum $204^{\circ} \mathrm{C}$ ) dan hampir sama dengan POE (pelumas dasar sintetis).

\section{Pour point}

Pour point atau titik tuang menunjukkan temperatur terendah di mana pelumas masih dapat mengalir, khhususnya pada saat mesin akan dihidupkan. Titik tuang minyak jarak pagar lebih rendah dibandingkan dengan pelumas dasar mineral. Jika titik tuang minyak jarak pagar dibandingkan dengan minyak nabati lain, nilainya lebih tinggi. Sebagian besar minyak nabati mempunyai titik tuang dibawah $0^{\circ} \mathrm{C}$ sedangkan minyak jarak pagar $0^{\circ} \mathrm{C}$. Jika dibandingkan dengan pelumas dasar sintesis (PAO), maka titik tuang minyak jarak pagar berada diatasnya.

Gambar 3 menunjukkan perbedaan flash point dan pour point beberapa jenis pelumas dasar yaitu pelumas dasar sintetis (PAO), POE dan minyak mineral terhadap minyak jarak pagar. 
Tabel 5. Klasifikasi pelumas industri menurut ISO (ASTM 2422)

Table 5. Classification of lubricant for industry according to ISO (ASTM 2422)

\begin{tabular}{|c|c|c|c|}
\hline \multirow{2}{*}{$\begin{array}{l}\text { Identifikasi kualifikasi } \\
\text { sistem viskositas } \\
\text { (Viscosity system grade } \\
\text { identification) } \\
\text { ISO VG } 2\end{array}$} & \multirow{2}{*}{ 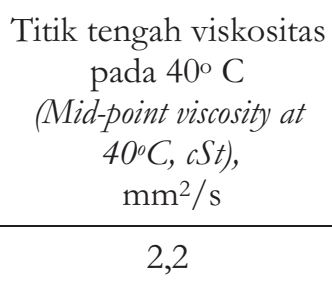 } & \multicolumn{2}{|c|}{$\begin{array}{c}\text { Limit kinematik viskositas pada } 40{ }^{\circ} \mathrm{C} \\
\text { (Kinematic viscosity limits at } 40^{\circ} \mathrm{C} \text { (St), } \\
\mathrm{mm}^{2} / \mathrm{s}\end{array}$} \\
\hline & & 1,98 & 2,42 \\
\hline ISO VG 3 & 3,2 & 2,88 & 3,52 \\
\hline ISO VG 5 & 4,6 & 4,14 & 50,6 \\
\hline ISO VG 7 & 6,8 & 6,12 & 7,48 \\
\hline ISO VG 10 & 10 & 9,00 & 11,0 \\
\hline ISO VG 15 & 15 & 13,5 & 16,5 \\
\hline ISO VG 22 & 22 & 19,8 & 24,2 \\
\hline ISO VG 32 & 32 & 28,8 & 35,2 \\
\hline ISO VG 46 & 46 & 41,4 & 50,6 \\
\hline ISO VG 68 & 68 & 61,2 & 74,8 \\
\hline ISO VG 100 & 100 & 90,0 & 110 \\
\hline ISO VG 150 & 150 & 135 & 165 \\
\hline ISO VG 220 & 220 & 198 & 242 \\
\hline ISO VG 320 & 320 & 288 & 352 \\
\hline ISO VG 460 & 460 & 414 & 506 \\
\hline ISO VG 680 & 680 & 612 & 748 \\
\hline ISO VG 1000 & 1000 & 900 & 1100 \\
\hline ISO VG 1500 & 1500 & 1350 & 1650 \\
\hline
\end{tabular}

Sumber (Source) : La Puppung (1986) 


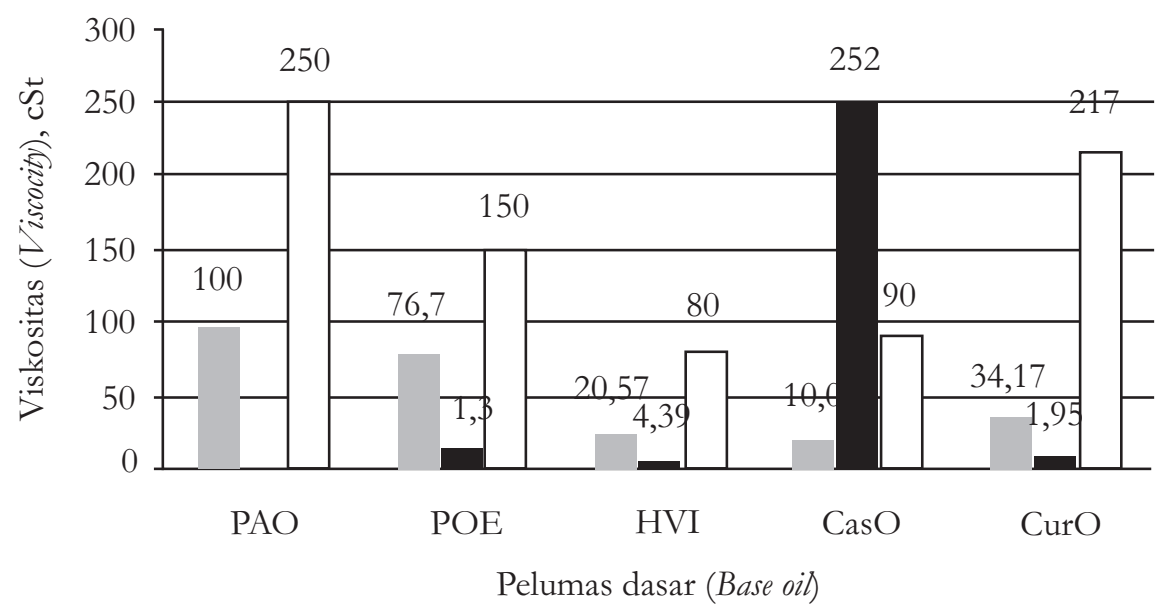

Viskositas $40^{\circ} \mathrm{C}$ Viskositas $100^{\circ} \mathrm{C} \square$ Indeks viskositas

Keterangan (Remarks) $: \mathrm{PAO}=$ Polyalphaolefin $; \mathrm{POE}=$ Polyolester $; \mathrm{HVI}=$ Indeks viskositas tinggi (High viscosity index) $\mathrm{CasO}=$ Minyak jarak (Castor oil); dan $\mathrm{CurO}=$ Minyak jarak pagar (Jatropha curcas oil)

Gambar 2. Viskositas dan indeks viskositas pelumas dasar (La Puppung, 1986)

Figure 2. Viscosity and viscosity index of lubricant base oil (La Puppung, 1986)

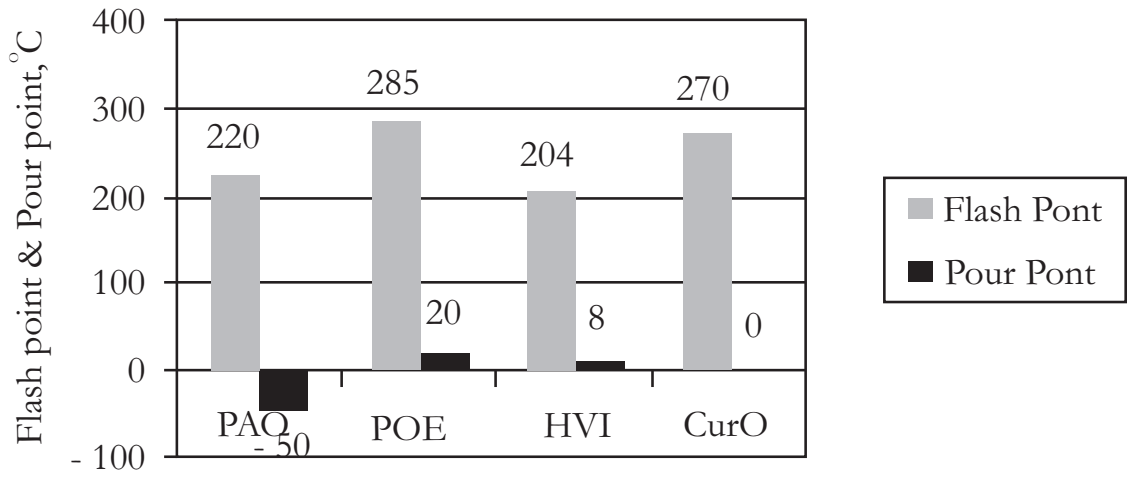

Pelumas dasar (Base oil)

Keterangan $($ Remarks $):$ PAO $=$ Polyalphaolefin; $\mathrm{POE}=$ Polyolester; HVI $=$ Indeks viskositas tinggi (High viscosity index); dan $\mathrm{CurO}=$ Minyak jarak pagar (Jatropha curcas oil)

Gambar3. Perbedaan antara flash point dan pour point pelumas dasar (La Puppung, 1986)

Figure 3. The difference between flash point and pour point of lubricant base oil (La Puppung, 1986) 


\section{Kerapatan}

Kerapatan merupakan berat persatuan volume. Tabel konversi yang meliputi kerapatan, berat jenis dan API gravity diberikan oleh American Petroleum Institute dan ASTM. Hubungan antara API gravity dan berat jenis adalah berbanding terbalik, dimana nilai API gravity yang tinggi akan memberikan berat jenis yang rendah. Pada pelumas dasar petroleum dan hidrokarbon, gravity digunakan untuk membedakan antara parafinik, naftenik, dan struktur aromatik. API gravity minyak binatang atau tumbuhan mempunyai nilai lebih rendah dan nilai berat jenis lebih tinggi dibandingkan dengan petroleum. Pada Gambar 4 terlihat bahwa kerapatan minyak tumbuhan lebih tinggi dibandingkan dengan petroleum.

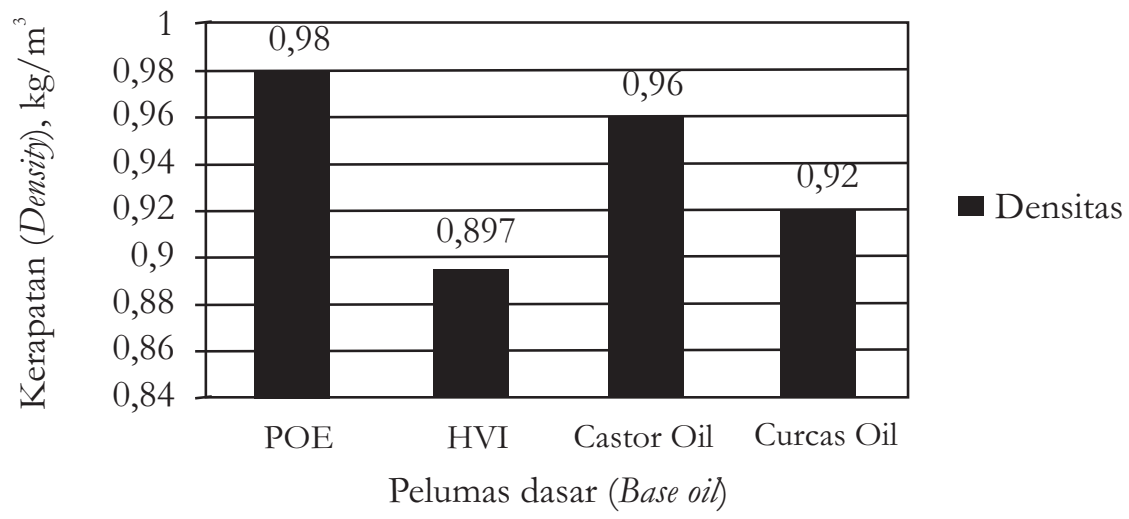

Keterangan $($ Remarks $): \mathrm{PAO}=$ Polyalphaolefin $; \mathrm{POE}=$ Polyolester $; \mathrm{HVI}=$ Indeks viskositas tinggi (High viscosity index); dan CurO = Minyak jarak pagar (Jatropha curcas oi)

\section{Gambar 4. Kerapatan beberapa pelumas dasar (La Puppung, 1986) Figure 4. Density of some lubricant base oils (La Puppung, 1986)}

\section{Sifat Kimia Minyak Jarak Pagar}

Minyak nabati merupakan minyak yang larut dalam air, yang berasal dari tumbuhan. Kandungan utama minyak nabati adalah ester gliserol dari asam lemak yang disebut trigliserida. Trigliserida merupakan ester dari satu molekul gliserol dengan tiga molekul asam lemak. Jenis asam lemak dalam trigliserida sangat mempengaruhi sifat-sifat trigliserida yang dibentuknya. Pada umumnya asam lemak yang terkandung di alam memiliki jumlah atom $\mathrm{C}$ genap dan masing-masing asam lemak dibedakan antara satu dan lainnya berdasarkan jumlah atom karbon dalam rantai, jumlah dan letak ikatan rangkap antara atom karbon. Asam lemak yang membentuk trigliserida ada 2 macam yaitu asam lemak jenuh (saturated) yang tidak mengandung ikatan rangkap dan asam lemak tidak jenuh (unsaturated) yang mengandung ikatan rangkap satu (monounsaturated) atau lebih dari satu ikatan rangkap (polyunsaturated). Derajat ketidakjenuhan rata-rata dari asam lemak atau campuran asam lemak dinyatakan dengan bilangan iod. Asam lemak tidak jenuh kurang stabil bila dibandingkan dengan asam lemak jenuh. 
Beberapa keuntungan minyak nabati apabila digunakan sebagai pelumas dasar adalah : non-toxic, biodegradable, terbarukan, sifat lubrisitasnya baik dan indeks viskositas tinggi. Beberapa kelemahan minyak nabati adalah ketidakstabilannya terhadap oksidasi dan sifat pada temperatur rendahnya jelek. Oksidasi terjadi karena molekul-molekul pelumas bereaksi secara kimiawi dengan oksigen. Produk-produk oksidasi yang terbentuk akan mengentalkan pelumas. Pengaruh jelek terhadap pelumas yang mengalami oksidasi adalah naiknya viskositas dan menyebabkan bilangan asam naik, sehingga akan mengakibatkan karat dan keausan pada logam yang akhirnya akan menimbulkan endapan (deposit). Pada Tabel 6 terlihat kandungan asam lemak tidak jenuh beberapa jenis minyak nabati dibandingkan dengan minyak jarak pagar.

Minyak nabati dengan bilangan iod antara 50 - 130 bisa digunakan sebagai fluida hidraulik. Fluida dengan bilangan iod dibawah 50 mempunyai pour point yang tinggi karena kekurangan ketidakjenuhan, dan minyak nabati dengan bilangan iod di atas 130 cenderung tidak stabil karena mudah teroksidasi. Dari Tabel 2 dan Tabel 6 terlihat bahwa minyak jarak pagar dengan bilangan iod antara 97 - 108,5 pourpointnya rendah. Asam lemak dalam minyak nabati bersifat polar dan cenderung lebih efektif melekat pada permukaan logam dibandingkan dengan minyak mineral. Minyak jarak pagar dapat digunakan sebagai pelumas dasar, tetapi karena adanya ikatan rangkap (ketidakjenuhan) maka menjadi tidak stabil.

Tabel6. Kandungan asam lemak tidak jenuh yang ada dalam beberapa minyak nabati

Table 6. Compositions and contents of some vegetable unsaturated oil

\begin{tabular}{|c|l|l|c|}
\hline No. & \multicolumn{1}{|c|}{$\begin{array}{c}\text { Minyak nabati } \\
\text { (Vegetable oil) }\end{array}$} & \multicolumn{1}{|c|}{$\begin{array}{c}\text { Asam lemak tidak jenuh } \\
\text { (Unsaturated fatty acid) }\end{array}$} & $\begin{array}{c}\text { Bilangan iod } \\
\text { (Iod number) }\end{array}$ \\
\hline 1. & $\begin{array}{l}\text { Minyak jarak pagar } \\
\text { (Jatropha curcas oil) }\end{array}$ & $\begin{array}{l}\text { Asam oleat, } \mathrm{C}_{18} \mathrm{H}_{34} \mathrm{O}_{2}\left(\mathrm{C}_{18: 1}\right) \\
=47,929 \%\end{array}$ & $90-108,5$ \\
\hline 2. & $\begin{array}{l}\text { Minyak jarak } \\
\text { (Castor oil) }\end{array}$ & $\begin{array}{l}\text { Asam risionelat, } \mathrm{C}_{18} \mathrm{H}_{34} \mathrm{O}_{3} \\
\left(\mathrm{C}_{18: 1}\right)=89,5 \%\end{array}$ & $81-90$ \\
\hline 3. & $\begin{array}{l}\text { Minyak kelapa } \\
\text { (Coco oil) }\end{array}$ & $\begin{array}{l}\text { Asam oleat, } \mathrm{C}_{12} \mathrm{H}_{24} \mathrm{O}_{2}\left(\mathrm{C}_{12: 0}\right) \\
=48,0 \%\end{array}$ & 83,8 \\
\hline 4. & $\begin{array}{l}\text { Minyak kelapa sawit } \\
\text { (Palm oil) }\end{array}$ & $\begin{array}{l}\text { Asam oleat, } \mathrm{C}_{18} \mathrm{H}_{34} \mathrm{O}_{2}\left(\mathrm{C}_{18: 1}\right)= \\
38 \%\end{array}$ & $107-137$ \\
\hline 5. & $\begin{array}{l}\text { Minyak kedelai } \\
\text { (Soybean oil) }\end{array}$ & $\begin{array}{l}\text { Asam linoleat \& } \mathrm{Asam}_{18} \\
\text { linolenat, } \mathrm{C}_{18} \mathrm{H}_{32} \mathrm{O}_{2}\left(\mathrm{C}_{18: 2}\right) \& \\
\mathrm{C}_{18} \mathrm{H}_{30} \mathrm{O} 2\left(\mathrm{C}_{18: 3}\right)=75 \%\end{array}$ & 83 \\
\hline
\end{tabular}

Sumber (Source) : La Puppung (1986) 
Pada Gambar 5 terlihat perbandingan bilangan asam beberapa pelumas dasar (minyak nabati, minyak mineral dan pelumas dasar sintesis). Bilangan asam adalah ukuran dari jumlah asam lemak bebas, serta dihitung berdasarkan berat molekul dari asam lemak atau campuran asam lemak. Pada Gambar 5 terlihat bahwa bilangan asam minyak jarak pagar lebih besar dibandingkan dengan minyak jarak castor, hal ini disebabkan karena kenaikan bilangan asam yang terjadi karena proses hidrolisa atau oksidasi pada minyak terutama terhadap ikatan rangkapnya.

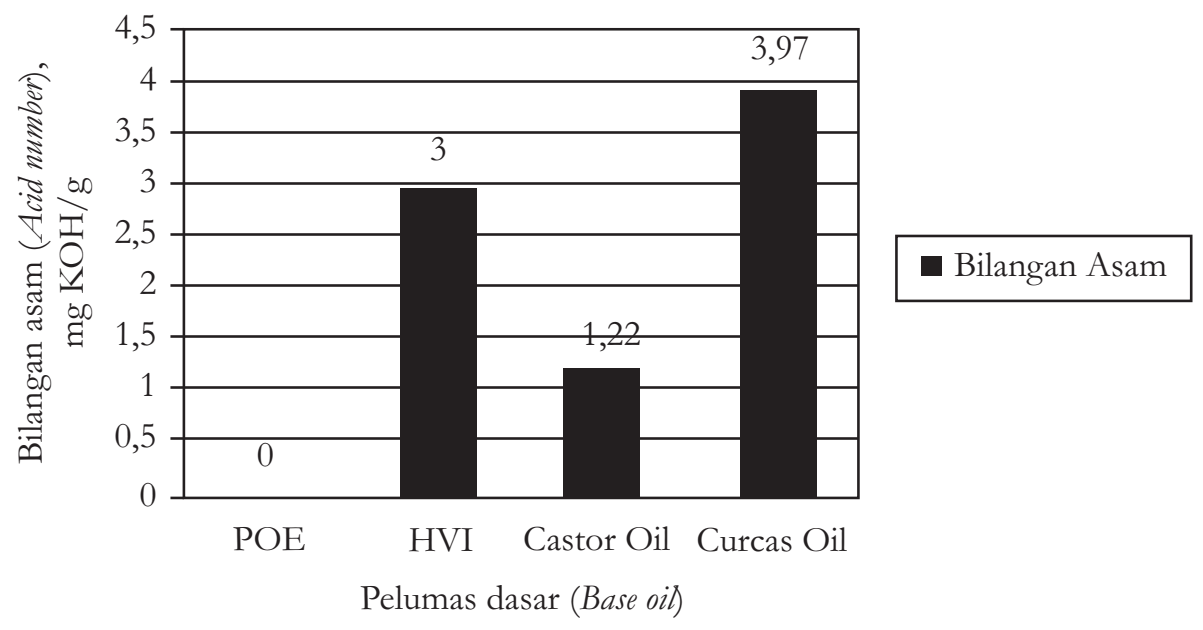

Keterangan $($ Remarks $):$ POE $=$ Polyolester $; \mathrm{HVI}=$ Indeks viskositas tinggi $($ High viscosity index $) ; \mathrm{CaO}$ $=$ Minyak jarak (Castoroil); dan CurO = Minyak jarak pagar (Jatropha curcas oil)

\section{Gambar 5. Bilangan asam beberapa pelumas dasar (La Puppung, 1986) Figure 5. Acid number of some lubricant base oils(La Puppung, 1986)}

Ikatan rangkap pada minyak nabati ditunjukkan dari bilangan iod-nya, terlihat pada Tabel 5. Semakin tinggi bilangan asam semakin besar kemungkinan terjadinya korosi. Jika dibandingkan dengan pelumas ester sintesis polyolester (POE), yaitu ester yang dibuat dari minyak nabati atau hewani dengan mono-, di- atau poli-alkohol dari petroleum. Oleokimia ini bersifat lebih stabil dibandingkan dengan natural ester, hal ini terlihat dari nilai bilangan asam minyak jarak pagar yang lebih besar dibandingkan dengan POE.

Pemeriksaan FTIR minyak jarak pagar memberikan spektrum yang dapat dilihat pada Gambar 6. Pada spektrum tersebut terlihat adanya pita serapan yang lebar di daerah bilangan gelombang $=2800-2980 \mathrm{~cm}-1$, yang menunjukkan adanya vibrasi ulur $\mathrm{C}-\mathrm{H}$ dari gugus $\mathrm{CH} 2$ dan $\mathrm{CH} 3$ serta 1 pita serapan kecil pada bilangan gelombang $3050 \mathrm{~cm}-1$ untuk gugus tidak jenuh alkena $\mathrm{CH}=\mathrm{CH}$-. Pita serapan pada panjang gelombang $1720 \mathrm{~cm}-1$ menunjukkan bahwa adanya gugus karbonil $>\mathrm{C}=\mathrm{O}$ dari esternya.

Dari uji Gas Chromatography (GC) terhadap minyak jarak pagar, seperti terdapat pada Gambar 7 dan Tabel 6 terlihat bahwa kandungan tertinggi dalam minyak jarak pagar adalah asam oleat $(47,9 \%)$ dengan satu ikatan rangkap. 


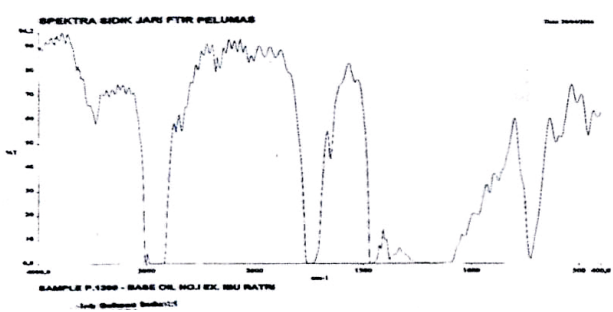

Gambar 6. Hasil uji FTIR Minyak Jarak Pagar Figure 6. Results of FTIR analyses

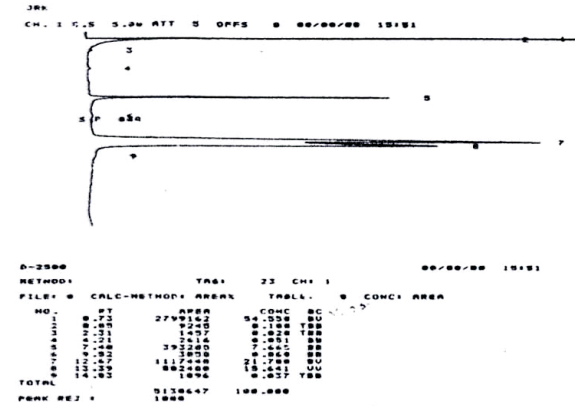

Gambar 7. Hasil Uji Gas Chromatography Figure 7. Results of chromatography analyses

Sifat minyak nabati yang dapat digunakan sebagai pelumas dasar harus mempunyai spesifikasi sebagai berikut:

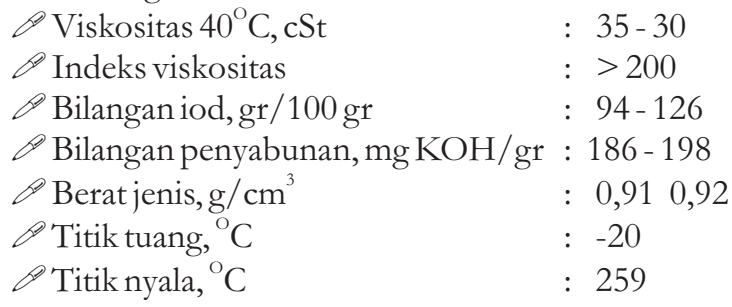

Pada Tabel 7 terlihat bahwa sifat fisik dan kimia minyak jarak pagar dapat memenuhi persyaratan sebagai pelumas dasar, kecuali pada persyaratan bilangan penyabunan dan pour point. Hal ini disebabkan karena bilangan penyabunan menunjukkan jumlah minyak yang dapat tersabunkan, minyak dengan berat molekul tinggi akan mempunyai bilangan penyabunan yang lebih rendah dibandingkan dengan minyak dengan berat molekul yang lebih rendah. Pour point minyak jarak pagar di atas spesifikasi pelumas dasar, hal ini menunjukkan bahwa minyak jarak pagar tidak bisa digunakan di daerah dengan suhu dibawah $0^{\circ} \mathrm{C}$.

Berdasarkan pada sifat kimia dan fisik dan hasil penguraian FTIR dan GC, maka modifikasai terhadap minyak minyak jarak pagar perlu dilakukan untuk memperbaiki sifat fisik dan kimianya. Beberapa contoh modifikasi yang dapat dilakukan adalah interesterifikasi dengan minyak nabati berpotensi yang lain, blending dengan ester sintestis untuk meningkatkan sifat pada temperatur rendah, transesterifiikasi dengan beberapa poliol, atau memodifikasi dengan mengurangi ketidakjenuhan. Sehingga minyak menjadi lebih stabil. Dari uraian sifat fisik dan kimia di atas, maka dapat disimpulkan bahwa minyak jarak pagar mempunyai potensi sebagai pelumas dasar, tetapi ada beberapa modifikasi yang perlu dilakukan untuk menigkatkan kestabilannya.

\section{Sintesis Epoksi Minyak Jarak Pagar}

Reaksi epoksidasi antara minyak jarak pagar dengan hidrogen peroksida dan asam asetat adalah untuk menghasilkan epoksidasi minyak jarak pagar yang akan dimanfaatkan oleh 
Tabe1 7. Sifat fisik dan kimia minyak jarak pagar sebagai pelumas dasar Table 7. Pbysical and chemical properties of jatropha oil as lubricant base oil

\begin{tabular}{|l|c|}
\hline \multicolumn{1}{|c|}{ S if a t (Properties) } & Nilai (Value) \\
\hline Kerapatan (Density), $\mathrm{kg} / \mathrm{m}^{3}$ & 0,9157 \\
\hline Titik nyala (Flash Point), ${ }^{\circ} \mathrm{C}$ & 270 \\
\hline Titik tuang (Pour Point) ${ }^{\circ} \mathrm{C}$ & 0 \\
\hline Viskositas (Viscosity) $40^{\circ} \mathrm{C}, \mathrm{cSt}$ & 34,17 \\
\hline Viskositas (Viscosity) $100^{\circ} \mathrm{C}, \mathrm{cSt}$ & 7,95 \\
\hline Indeks viskositas $($ Viscosity index) & 217 \\
\hline Indeks bias $25^{\circ} \mathrm{C}$ & 1,4655 \\
\hline $\begin{array}{l}\text { Bilangan penyabunan (Saponification } \\
\text { number), mg KOH/gr }\end{array}$ & 96,7 \\
\hline Bilangan iod (Iod number), gr/100 gr & 108,5 \\
\hline
\end{tabular}

industri polimer dan plastik sebagai plasticizer seconder. Tetapi dalam penelitian ini tujuan pembuatan epoksi adalah untuk digunakan sebagai bahan baku pembuatan poliol atau minyak pelumas nabati.

Dalam proses epoksidasi ini, untuk mengetahui pengaruh variabel pada proses epoksidasi minyak jarak, maka diperlukan berbagai macam variasi percobaan diantaranya, percobaan dilakukan pada suhu konstan dengan menggunakan katalis asam sulfat $1 \% \mathrm{v} / \mathrm{v}$, dan menggunakan variabel perlakuan perbandingan konsentrasi hidrogen peroksida-asam asetat $\left(\mathrm{H}_{2} \mathrm{O}_{2}\right)$ dengan $\left(\mathrm{CH}_{3} \mathrm{COOH}\right)$ sebagai berikut : $1: 0,07 ; 1: 0,15 ; 1: 0,22$ dan $1: 0,30$. Lama proses bervariasi yaitu : $0 ; 0,5 ; 1,0 ; 1,5 ; 2,0 ; 2,5 ; 3,0 ; 3,5 ; 4,0 ; 4,5 ; 5,0$ dan 5,5 jam. Hasil penelitian pada variasi konsentrasi tersebut dapat di lihat pada Tabel 8.

Hasil penelitian yang terdapat pada Tabel 8 dapat dilihat bahwa dari perbandingan pereaktan yang dilakukan, diperoleh bilangan oksiran, di mana pada variasi $1: 0,07 \mathrm{~mol}$ diperoleh bilangan oksiran yang terus mengalami peningkatan yang cukup signifikan hingga mencapai $4,25 \%$ pada 30 menit ke- 6 . Hal ini disebabkan seiring dengan bertambahnya waktu reaksi, maka kesempatan molekul molekul zat pereaksi untuk saling bertumbukan semakin luas, sehingga diperoleh konversi minyak nabati yang semakin meningkat. Pada 30 menit ke-7 mengalami penurunan bilangan oksiran hingga mencapai 3,9\% di mana hal ini dapat dimungkinkan karena epoksidasi merupakan reaksi bolak balik yang berpotensial untuk diikuti reaksi samping, sehingga epoksidasi sebaiknya dilakukan sesingkat mungkin. Kecepatan pembukaan rantai epoksi 9,10-epoksi stearat asam oleat terepoksidasi berlangsung $1 \% /$ jam pada $25^{\circ} \mathrm{C}$ dan $100 \%$ per 1 - 4 jam pada suhu $65^{\circ} \mathrm{C}-100^{\circ} \mathrm{C}$ (Kirk dan Othmer, 1982). 
Tabel 8. Pengaruh perbandingan konsentrasi hidrogen peroksida dengan asam asetat terhadap bilangan oksiran (suhu $60^{\circ} \mathrm{C}$, katalis $\mathrm{H}_{2} \mathrm{SO}_{4} 1 \% \mathrm{v} / \mathrm{v}$ )

Table 8. Effect of bydrogen peroxide to acetic acid contration ratio on oxyrane number

\begin{tabular}{|c|c|c|c|c|}
\hline \multirow{2}{*}{$\begin{array}{c}\text { W a k t u } \\
\text { (Time) }\end{array}$} & \multicolumn{4}{|c|}{ Bilangan oksiran (Oxyrane number) } \\
\cline { 2 - 5 } & $1: 0,07$ & $1: 0,15$ & $1: 0,22$ & $1: 0,30$ \\
\hline 0 & 0 & 0 & 0 & 0 \\
\hline 0,5 & 2,12 & 2,65 & 3,91 & 3,30 \\
\hline 1 & 3,55 & 3,38 & 4,15 & 4,24 \\
\hline 1,5 & 3,80 & 3,78 & 4,37 & 4,59 \\
\hline 2 & 4,07 & 4,07 & 4,59 & 4,94 \\
\hline 2,5 & 4,16 & 4,32 & 4,68 & 4,96 \\
\hline 3 & 4,26 & 4,74 & 4,78 & 4,96 \\
\hline 3,5 & 3,93 & 4,75 & 4,86 & 4,89 \\
\hline 4 & - & 4,81 & 4,93 & 4,75 \\
\hline 4,5 & - & 4,82 & 4,63 & 4,70 \\
\hline 5 & - & 4,90 & 4,3 & 4,60 \\
\hline 5,5 & - & 4,71 & - & - \\
\hline
\end{tabular}

Pada perbandingan 1:0,15 mol, bilangan oksiran terbaik adalah 4,9\% pada 30 menit ke10 dan kemudian mengalami penurunan pada 30 menit ke-11, dengan bilangan oksiran yang diperoleh 4,71\%. Sedangkan pada variasi 1 : $0,22 \mathrm{~mol}$ dan $1: 0.3 \mathrm{~mol}$ diperoleh bilangan oksiran yang hampir sama (cenderung konstan) dengan variasi perbandingan 1 : 0,15 mol yang memberikan kenaikan bilangan oksiran seiring dengan waktu reaksi, dengan bilangan oksiran yang diperoleh yaitu 4,93\% pada 30 menit ke- 8 dan $4,96 \%$ pada 30 menit ke- 5 .

Pada Tabel 8 terlihat bahwa semakin besar konsentrasi zat pereaksi (asam asetat), dapat meningkatkan kecepatan reaksi. Hal ini dikarenakan, semakin besar konsentrasi zat pereaksi, maka frekuensi terjadinya tumbukan antara molekul molekul yang bereaksi juga semakin besar (Gan et.al, 1992). Dari data yang diperoleh terlihat bahwa, semakin besar konsentrasi asam asetat, maka waktu yang diperlukan untuk memperoleh bilangan oksiran yang tinggi juga lebih singkat, sehingga selain berfungsi sebagai pereaksi, juga dapat berfungsi sebagai semi katalis pada pembentukan asam perasetat. 


\section{KESIMPULAN DAN SARAN}

1. Sifat fisik dan kimia minyak jarak pagar, memenuhi persyaratan sebagai pelumas dasar kecuali pada persyaratan bilangan penyabunan dan pour point. Karakteristik tersebut adalah : kerapatan $0,9157 \mathrm{~kg} / \mathrm{m}^{3}$; flash point $270^{\circ} \mathrm{C}$; pour point $0^{\circ} \mathrm{C}$; viskositas $40^{\circ} \mathrm{C}(\mathrm{cSt})$ 34,17; viskositas $100^{\circ} \mathrm{C}$ (cSt) 7,95; viskositas indeks 217; indeks bias $25^{\circ} \mathrm{C} 1,4655$; bilangan penyabunan $96,7 \mathrm{mg} \mathrm{KOH} / \mathrm{gr}$ dan bilangan iod 108,5 gr/100 gr.

2. Sifat kimia dan fisik hasil pengujian FTIR dan GC menunjukkan perlunya perbaikan sifat fisik dan kimia minyak jarak pagar. Beberapa contoh modifikasi yang dapat dilakukan adalah interesterifikasi dengan minyak nabati yang lebih baik, blending dengan ester sintestis untuk meningkatkan sifat bahan pelumas pada temperatur rendah, mengurangi ketidakjenuhan sehingga minyak menjadi lebih stabil.

3. Perbedaan penambahan konsentrasi asam asetat dengan hidrogen peroksida berpengaruh terhadap bilangan oksiran pada senyawa epoksi yang dihasilkan.

4. Pada kisaran percobaan yang dilakukan, kondisi terbaik dicapai pada 3 jam operasi dengan suhu $60^{\circ} \mathrm{C}$ dan perbandingan konsentrasi hidrogen peroksida-asam asetat $\left(\mathrm{H}_{2} \mathrm{O}_{2}\right)$ $\left(\mathrm{CH}_{3} \mathrm{COOH}\right)$ adalah $1: 0,07$ mol dengan besarnya bilangan oksiran 4,26\%.

5. Masih diperlukan penelitian lanjutan khususnya mengenai teknologi pengolahan epoksi menjadi minyak pelumas (poliol).

\section{DAFTAR PUSTAKA}

Askew, M.F. 2004. Bio-lubricants Markets Data Sheet. IENICA Inform Project.

Gan, L.H., S.H. Goh. \& K.S. Ooi. 1992. Kinetic Studies of Epoxidation and Oxirane Cleavages of Palm Olein Methyl Esters". JAOCS, Vol. 69.

Güibitz, G.M., M. Mittelbach \& M. Trabi. 1999. Exploitation of the tropical oil seed plant Jatropha curcas L. Bioresource Tech. 67:73-82.

Kirk, R.E. \& Othmer, D.F. 1982. Encyclopedia of Chemical Technology. Vol. 8 9, Third edition, John Wiley and Sons. New York.

La Puppung. 1986. Minyak jarak memiliki potensi sebagai bahan dasar minyak pelumas. Lembaran Publikasi Lemigas 4: 55 64. Jakarta.

Nugroho, A. 2005. Ensiklopedia Otomotif. Penerbit Gramedia Pustaka Utama. Jakarta.

Sudradjat, R. 2006. Memproduksi biodiesel jarak pagar. Solusi hasilkan biodiesel berkualitas tinggi. Penerbit Penebar Swadaya Seri Agritekno. Jakarta. 